\title{
Dance Studies/Cultural Studies
}

\author{
Gay Morris
}

\section{Introduction}

n the mid-rggos several articles appeared in the dance literature calling for a greater

alliance between dance scholarship and cultural studies. More recently, dance scholarship has come to be labeled "dance studies," suggesting that such a link has occurred. Since interdisciplinarity is a key element of cultural studies, it is appropriate to investigate interdisciplinarity in dance studies by examining dance's relationship to cultural studies. ${ }^{1}$ This genealogical task, though, is not as straightforward as it might seem. Cultural studies' relationship to the disciplines has not been stable over its half-century of existence. Interdisciplinarity, tied so closely to cultural studies'idea of its own freedom and political mission, has proved difficult to hang onto-so difficult, in fact, that today some consider the field to be in crisis. To complicate matters further, dance and cultural studies developed along different paths; consequently, interdisciplinarity within dance studies is not always conceptualized in the way it is in cultural studies. Cultural studies was initially meant as a political and social intervention that purposefully avoided creating theories of its own, while dance research, long tied to the disciplines of history and anthropology, not only adopted many of the theories and methods of these fields but also developed theories and methods of its own as an aid in analyzing the human body in motion. Where and how, then, do dance and cultural studies meet on the grounds of interdisciplinarity? This is not an idle question; cultural studies has had a major impact on arts and humanities scholarship, and as cultural studies reaches a critical moment of reexamination, new questions arise as to the role of interdisciplinarity, both in cultural studies and in the fields it has so profoundly influenced. ${ }^{2}$

In this essay I will first discuss ways in which interdisciplinarity has been defined within dance studies. This will be followed by an extended examination of the concerns of early

Gay Morris is a dance and art critic whose work has appeared in numerous publications, including Dance Research, Dance Research Journal, Art in America, ARTnews, and Body and Society. She is the author of $A$ Game for Dancers: Performing Modernism in the Postwar Years, 1945-1960 (Wesleyan University Press, 2006), which won the 2007 De La Torre Bueno Prize for outstanding contribution to dance literature. She is also the editor of an anthology, Moving Words, Rewriting Dance (Routledge, 1996). 
cultural studies and critiques of the field that emerged after it expanded to the United States. The analysis of cultural studies is pursued in detail because it sets the stage for my central argument, which is that dance studies, while benefiting from many elements of cultural studies, may be able to avoid some of that field's later troubles by means of its focus on the living body. However, dance studies will succeed only if it can demonstrate that dance (defined in the broadest terms) has a significant social role to play. In short, dance studies must recuperate some of cultural studies' early engagement with pressing social and political issues, which was an essential part of its interdisciplinarity.

\section{Dance and Interdisciplinarity}

Jane Desmond, in an article published in 1993 in Cultural Critique, called for cultural studies to put dance on its agenda, arguing that dance research could further understanding of "how social identities are signaled, formed, and negotiated through bodily movement" $(1993,34)$. Conversely, dance could profit from cultural studies by using many of the tools developed in literary, film, and feminist theory, as well as Marxist analysis. By 1997 Desmond was arguing that new dance scholarship was utilizing theory that focused on the ideological foundations of aesthetic practices and as such was in tune with cultural studies (Desmond 1997, I-5). Dance scholars, she wrote, were employing critical theory to produce more sophisticated analyses of dance as a social practice, particularly in the realms of embodiment, identity, and representation. For Desmond, then, cultural studies was defined by interdisciplinarity, which meant the use of various poststructural, postmodern, and post-Marxist theories applied to cultural objects and social practices. Inclusion of social context and acknowledgement of historical contingency were essential parts of the process of doing cultural studies and hence of interdisciplinarity. By extension, dance became interdisciplinary by adding such theories and methods to those it already possessed.

Like Desmond, Amy Koritz argued in an essay entitled "Re/Moving Boundaries: From Dance History to Cultural Studies" (1996) that cultural studies would benefit from including dance in its purview. At the same time she called for dance scholars to broaden their scope and to speak more than one disciplinary language in order to participate in current intellectual debates. Koritz conceptualized interdisciplinarity as an intertwining of disciplines in order to answer questions that one discipline alone cannot or does not consider. She spoke of an "uneasiness with the ways in which disciplinary fields of knowledge have excluded particular kinds of questions or approaches" (1996, 99). In this she echoed Fredric Jameson's critique of cultural studies, in which he asserted that interdisciplinarity is nothing new in the academy and appears when individual disciplines omit or suppress different but necessary aspects of objects of study they should be sharing (Jameson 1993, 20). For Jameson, interdisciplinarity comes into being because of an inadequacy within the disciplines but finally, by definition, always fails.

Another call for dance to ally itself with cultural studies and an interdisciplinary approach was made by art historian Norman Bryson in an address at the groundbreaking Choreographing History conference held at the University of California at Riverside in 
1992. ${ }^{3}$ An expanded version of Bryson's talk appeared in 1997 in Jane Desmond's collection Meaning in Motion: New Cultural Studies of Dance. In the published version of his talk, Bryson suggested that cultural studies could influence the dance field in positive ways. He said that thanks to the breakdown of the strict division between base and superstructure, dance, as an element of culture, could now be shown to have close ties with historical power and change. This, in turn, could make dance an attractive addition to cultural studies departments. At the same time, it could lead dance scholars to broaden their intellectual horizons, not only incorporating elements of critical and cultural theory into their work but also reexamining the whole idea of what dance might be. A noncanonical definition of dance would call into question the place of high art dance and ask why particular works and artists were dominant. Instead of conceptualizing dance as a high-art theatrical form, Bryson would substitute a definition of dance as "socially structured movement." This would then open the field to a much wider scope of inquiry. He also tied dance study to social context and historical specificity, citing examples such as the ubiquity of the bow at the court of Versailles as a part of daily life, a means of social acceptance, a measurement of symbolic capital, and a facet of economic exchange. This kind of study he called "social kinetics" or "anthropology of movement." Finally, he pointed out how dance scholars could find useful methods and concepts in fields such as art history, film theory, and comparative literature.

More recently Susan Manning discussed the "studies" formation in relationship to interdisciplinarity in a "Letter from the President," which appeared in the Society for Dance History Scholars Newsletter (Manning 2006). Describing the shift in usage from "dance history" to "dance studies," she referred to interdisciplinarity as a key element in the new designation. The term "studies," she said, reflects "a blurring of boundaries between previously distinct subfields and a heightened exchange between dance and other fields of scholarly inquiry" (Manning 2006, I-2). This definition, she said, leads to three variant meanings: the first is the "theoretical turn," which the dance field has taken in the last twenty years; the second is the breakdown of barriers between dance history and dance ethnography; and the third is a closer link between dance practice and theory.

Manning, like Desmond and Koritz, conceives interdisciplinarity in terms of the dance field adding methods and theories from other fields. Manning also sees interdisciplinarity as a merging of subfields of dance, exemplified by history and anthropology. Similarly, dance practice and theory are being brought closer together. Unlike Koritz, Manning does not say why one might want to blur disciplinary boundaries, nor does she suggest, as Bryson does, that dance be radically expanded to include socially structured movement of all kinds.

\section{Early Cultural Studies as Intervention}

So far we have seen dance scholars conceptualizing cultural studies primarily in terms of interdisciplinarity, but is it the same interdisciplinarity as that of cultural studies? As will be shown, the answer is yes and no. But first it is necessary to turn to an examination of the legacy and problems of cultural studies, which then makes possible a discussion 
of how dance studies and cultural studies interrelate around the central role of interdisciplinarity.

Cultural studies, at least in the early days, did not fit the dance studies model of a field expanding an already established body of knowledge. Cultural studies was intended, first of all, to be a social and political intervention. Its scholars prided themselves on having no theories or methods of their own; they borrowed whatever was needed, which might be different in each specific case, to accomplish an interventional end. Stuart Hall, one of the pioneers of cultural studies, made it clear on numerous occasions that the point of cultural studies was not to study culture per se but to understand what was going on in order "to make a difference in the world" (Hall 1992, 278).

Richard Hoggart's The Uses of Literacy (1957/2006), the earliest of what are generally considered cultural studies' foundational texts, already pointed in a direction that linked interdisciplinarity and intervention. In The Uses of Literacy Hoggart used Leavisite close readings, traditionally reserved for "serious" literature, to examine popular media such as family magazines, sex-and-violence novels, and the lyrics of popular songs. ${ }^{5} \mathrm{Hog}-$ gart had meant to use this material as a textbook for the adult education classes he was teaching in the mid-I950s for the University of Hull (1957/2006, 271-72), but he wasn't satisfied with the result. He felt that to more fully explain the implications of his analysis, he needed to include social context. Therefore, he added what became the first part of the book, a description of working-class values based on his own experience. His point was that although mass media was making its mark on working-class values, traditional values were strong enough to resist much of what the media was propounding. Although Hoggart was not optimistic about the ability of working-class people to continue their resistance, and found an antidote in teaching them to appreciate "good" literature, this was nonetheless the beginning of a focus on contemporary culture, mass media, and class that would become key to cultural studies in the United Kingdom.

Hoggart's book also indicated a desire to come to grips with issues that neither literary criticism nor sociology were dealing with and a willingness to cross disciplinary boundaries in order to do it. At the same time, Hoggart countered formalist literary analysis by introducing the element of time into his study, by making it historically specific rather than universal, and by dealing with transition rather than stability. For Hoggart, texts could not be separated from wider social practices and processes. Social context and specificity of time and place became other important elements for cultural studies. Hoggart's book was an intervention in that it not only implicitly critiqued the academy, but it also called into question current Marxist dogma, although it was not theorized as such. Hoggart refused to accept the idea that working-class people were the passive dupes of the culture industry. He defended working-class values and argued for working-class resistance, despite being pessimistic about the future.

Other early cultural studies texts, specifically Raymond Williams's Culture and Society (1958/r983) and the expansion of his thinking in The Long Revolution (1961), and E. P. Thompson's The Making of the English Working Class (1963), also were interventionist in intent. In Culture and Society Williams traced the history of the concept of "culture," finally defining it in two principal ways: as "certain moral and intellectual activities," those that 
Matthew Arnold called "the best that has been said and thought in the world"(Williams r958/1983, Ir5) and alternately as "a whole way of life" (1958/1983, xvi-xviii).

Williams argued against reductive Marxist theory, finding that economic organization could not be separated from culture. Base and superstructure, he said, do not appear in isolation but are inextricably bound together in immensely complex ways, and whether economics is finally the determining factor is impossible to answer ( $1958 / 1983,280-82$ ). Williams also contended that equating "the masses" with the working class was incorrect. In fact, there were no masses but merely stereotypes for the other-and the fear of change that went with it. So-called mass media were not working class, he said, in that they were not made especially for working-class people or by them (1958/1983, 319). Contrary to crude Marxist analysis, Williams maintained it was not useful to speak of intellectual or imaginative work as bourgeois or proletarian. Instead, he argued, differences in classes arise in social relations. Here Williams contrasted bourgeois social relations, built on concepts of individualism, with those of the working class, constructed on ideas of community. Bourgeois minds conceived society as a neutral area where the individual had the right to develop to his own advantage, while working-class thought conceptualized society as neither neutral nor protective but as a positive means for many kinds of development, including individual ones $(325-26)$.

Finally, Williams argued for a common culture that would bring together a dedication to the good of the community with tolerance for individual variety. Like Hoggart, Williams defended working-class values. But he went further, seeing these values as the basis of democracy. Williams's stress on culture as a whole way of life became basic to cultural studies. His leftist orientation and view that mass communications and popular culture were conduits of social relations also were formative. ${ }^{6}$

Thompson, in his history of the English working class, viewed class consciousness as a cultural as much as an economic formation. Like Hoggart and Williams, he defended the English working class, demonstrating that class consciousness had not just spontaneously appeared at the Industrial Revolution but had developed over several centuries and was due as much to people's agency as to conditioning. Class was not a structure or category but a relationship "embodied in real people and in a real context" $(1963,9)$. It was the result of common experiences that forged an identity: "Class-consciousness is the way in which these experiences are handled in cultural terms: embodied in traditions, values, systems, ideas, and institutional forms"(то). Thus Thompson, like Hoggart and Williams, saw culture as key to understanding struggles and change within capitalism.

Thompson criticized contemporary Marxism (although not Marx's own work) for considering the working class as a "thing" with an existence of its own rather than as a relationship. He also questioned the sociological view of class as an objectified, static structure and class consciousness as a role within the social structure. "Class," Thompson argued, "is defined by men as they live their own history" ( $\left.\mathrm{I}_{963}, \mathrm{II}\right)$. In making his case, Thompson stressed what would become important concepts in cultural studies. These included historical and geographical specificity (Thompson made it clear he was speaking of the English working class, not the Scottish or Welsh, from the late eighteenth century through the 1830 ) and context seen in relational terms. He also emphasized what would 
come to be called "conjuncture," in cultural studies, that is, the coalescence at certain moments of disparate, often conflicting, and seemingly unconnected events.

Cultural studies came of age in postwar England, a period of social and political transition as the country adopted welfare capitalism and the Cold War took hold. Political, economic, and social relationships were shifting, raising a host of questions. In their seminal texts, Hoggart, Williams, and Thompson focused on the English working class as representative of the tensions between traditional and newly developing values and ways of life. Each in his own way insisted that struggles within society were fought not only on an economic but on a cultural level, and each called into question the relationship of base/superstructure. Their interest was not academic; it grew out of their own experience. Hoggart and Williams came from working-class families, while Thompson, whose parents were former Methodist missionaries in India, was active in leftist politics. These men had a personal stake in investigating the role of culture in society, and they were, as Hall has noted, "cultural interventions in their own right" $\left(\right.$ I980a, I6).${ }^{8}$ Another aspect of their experience contributed to the interventionist focus of cultural studies: they were not initially at the center of academic education. Rather, Hoggart, Williams, Thompson, and later Stuart Hall taught adult extension courses. According to Williams, their own and their students' distance from the academic mainstream gave them the latitude to think outside academic structures and organizations of knowledge (Williams 1989, 159-62; see also Hall 1990,12$)$.

Cultural studies was only institutionalized when Hoggart was hired as a professor of modern English literature at the University of Birmingham in 1962 and two years later initiated the Centre for Contemporary Cultural Studies (CCCS). ${ }^{9}$ Hoggart engaged Stuart Hall as his assistant, with Hall becoming director for a decade beginning in 1968 . Williams and Thompson were not associated with CCCS. However, in 1960 Thompson, with Williams, Hall, and others, helped found the New Left Review, which marked the beginning of the New Left in Britain. ${ }^{10}$ The element of political activism, then, was an important factor in early cultural studies. Hall, although emphasizing the idea that cultural studies is "not just one thing," consistently characterized it as activist in intent.

Hoggart and Williams's early work called into question the ability of established disciplines to deal with pressing contemporary questions. They were addressing issues in ways that bridged the humanities and social sciences and at the same time implicitly critiqued them. Both men were trained in literature, however, as was $\mathrm{Hall},{ }^{11}$ and they primarily used methods of textual analysis, combining it with sociological and historical inquiry but not sociological methods (at the time primarily empirical and positivist) or archival research. The tendency toward textuality would eventually become a contentious point for cultural studies. But by then textuality would mean not only the privileging of textual analysis but also what was considered an excessive dependence on discursive theory.

Early on, work at CCCS was political in the sense that it focused on class issues and questioned Marxist theory as it was known at that time in Britain. Hoggart, Williams, and Thompson stressed the concreteness of experience and human agency. Hall's tenure was marked by a shift toward theorization, drawing especially on the work of continental Marxist theorists, which had hitherto been unavailable in Britain. The concepts of Al- 
thusser, then Gramsci and semiotic theory, and later gender, race, and postcolonial theory were gradually folded into cultural studies. According to Hall, early cultural studies treated Marxism as a problem, not a theory, and accordingly worked against, with, and on it. This was due in part to the fact that the field emerged in the late I950s after the Soviet invasion of Hungary, when an older form of Marxism was disintegrating. Marxism was never a perfect fit with cultural studies, Hall said; it was always a problem to be struggled with (Hall 1992, 279-80).

During the I970s and I980s scholars at CCCS published important studies on youth culture, education, media, and race, with class a continuing concern. Among them were Dick Hebdige's Subculture: The Meaning of Style (1979/1996) and Paul Willis's Learning to Labor: How Working Class Kids Get Working Class Jobs (1977). Collaborative work was key during those years, as evidenced by books produced primarily by postgraduates and sometimes edited by Hall, such as Resistance through Rituals: Youth Subcultures in Post War Britain (Hall and Jefferson 1976), Policing the Crisis: Mugging, the State, and Law and Order (Hall et al. 1978), and The Empire Strikes Back: Race and Racism in 7os Britain (CCCS I982).

Policing the Crisis was among the most successful of this work. The study was sparked by an incident in Birmingham in which three youths mugged and badly injured a man who was on his way home from a pub. The authors made it clear that they were not doing a sociological case study or a practical guide on how to clean up crime in Britain. Their aim was larger, namely, to analyze the conditions that produced both crime and a particular response to it at a specific place and moment. They viewed "mugging" as relational, that is, as crime in relation to the response to it; and they also examined the subject in terms of historical conjuncture. They argued that crime in Britain had come to be seen as an index of the disintegration of the social order. This had led to a backlash for more lawand-order. The authors analyzed how the ideology of law-and-order was constructed and who constructed it. They claimed that race, crime, and youth had coalesced into a sign of "mugging,"which served as an ideological conductor, or mechanism, for an authoritarian consensus building toward an increased law-and-order society. Finally, they concluded that the response to crime at the time signaled a crisis of hegemony in British society.

Policing the Crisis demonstrated how cultural studies scholars at the CCCS crossed disciplinary boundaries that separated critical theory from sociology, insisting that theory be applied to historically specific cases in order to show what they considered to be hidden truths of capitalism. Politics, then, was an integral part of cultural studies' interdisciplinarity. However, the melding of experience and theory was not easily attained and was an ongoing struggle, as $\mathrm{Hall}$ and others have noted. Over time it became an increasingly contentious issue for cultural studies and remains so today, as the next two sections demonstrate.

\section{Cultural Studies in the United States}

Cultural studies gradually moved to the United States in the 1970 and 1980 and was well-established by the time of the cultural studies conference at the University of Illi- 
nois at Urbana in 1990 . This conference marked a high point in cultural studies influence and led to the important volume Cultural Studies (1992), edited by Lawrence Grossberg, Cary Nelson, and Paula Treichler. ${ }^{12}$ But the conference also exposed divisions within the field. It served as a site of critique for a number of the participants, and then extended beyond the conference itself, as reviews of Cultural Studies appeared in the wake of the book's publication.

The editors of Cultural Studies hinted at problems in their introduction, saying that in the United States it was unclear "what kind of work will be identified with cultural studies and what social effects it will have" (1992, 10). They noted that too many scholars were calling their work cultural studies when they were simply doing what they had done in the past. More specific were comments Hall made at the conference in which he noted the explosion of cultural studies and other forms of critical theory in the United States, calling it a moment of profound danger. That danger, he said, came from the very ease with which academics could now "theorize power-politics, race, class and gender, subjugation, domination, exclusion, marginality, Otherness, etc." (1992, 285-86). He was, he said, nagged by the thought that "this overwhelming textualization of cultural studies' own discourses somehow constitutes power and politics as exclusively matters of language and textuality itself" $(1992,286)$. He saw a disconnect between such fluency and what in less rarified circles might be called the "real world." Hall's remarks echoed ones he had made several years earlier in an article in the journal October, in which he stated: "those who are doing formal deconstruction of the most elegant, mannered kind are perfectly in touch with the advanced frontiers of theoretical work, yet their contribution to the resolution of the cultural crisis I have just named is nonexistent" (1990, 22). And even more pointedly: "It is perfectly possible to write elegant treatises on the 'other' without ever having encountered what 'otherness' is really like for some people actually to live" (1990, 23). For Hall, cultural studies was meant to work in tension between theory and politics. Theory was to be used as a tool to intervene in the world in order to bring about change. ${ }^{13}$

The sense that cultural studies was close to drowning in textuality was suggested by several other conference participants. These included Janet Wolff, who argued for an interdisciplinarity that integrated textual analysis with a study of the processes and institutions of cultural production. She called for an increased focus on lived experience. More extreme forms of discourse theory, she said, "deny either the independent existence of or access to, the 'real"' (1992,712). Speaking in terms of gender theory, she noted that however arbitrary cultural categories of gender may be, they constitute peoples' lived experience, "the basis of prejudice and inequality and the possibility for political organization. The permanently evanescent categories of poststructuralist theory preclude the possibility of mobilization and political action" (1992,713). In the United Kingdom, Wolff said, an interdisciplinarity that integrated textual analysis with social relations was often seen, but it was less evident in the United States, due, she felt, to the organization of disciplines and institutional obstruction. ${ }^{14}$

Bell hooks and Cornel West, both African Americans, also noted, in different ways, how the element of social relations was lacking in American cultural studies. In an essay on representations of whiteness in the black imagination, hooks stated that "Attending a 
recent conference on cultural studies, I was reminded of the way in which the discourse of race is increasingly divorced from any recognition of the politics of racism" (hooks 1992,345). At the conference she realized that although she had assumed she would be in the company of enlightened intellectuals, she found that hierarchies of white supremacy were nonetheless being reproduced in who spoke and how people were arranged on the stage. This produced in her the same feelings of fear she had experienced as a child walking through a white neighborhood. In a conversation among panelists, hooks spoke about the excitement of teaching feminist studies, in which she was able to use theory in a way that directly connected with the everyday life of her students. She missed this connection in cultural studies $(1992,702)$.

Cornel West also addressed the issue of divisions between theory and social relations. $\mathrm{He}$ argued for a necessary meeting of activism with the life of the mind, which he saw as segregated in the United States. The role of theory was to help people understand the circumstances in which they live, but, he said, this must be coupled with political action to have any effect $(1992,696)$. He spoke, too, about how popular music was for him and many others more than "some ornamental or decorative cultural object of investigation!" It was a sustaining force that made a profound difference in his life. "When we talk about popular culture we're talking about its materiality at the level of producing and sustaining human bodies" $(1992,695)$. hooks, through feminism, and West, through music, were able to deflect the academy's tendency toward abstraction and obscurantism. They echoed Hall's comments that cultural studies must do theoretically based, intellectual work that addressed real problems (1992, 28I). In his words: "I'm trying to return the project of cultural studies from the clean air of meaning and textuality and theory to the something nasty down below" (1992, 278).

Fredric Jameson, in an influential review of Cultural Studies that served as a critique of the field as a whole, supported Hall's concern that cultural studies had lost its political focus. First, he argued that culture and, hence, cultural studies were essentially concerned with group relationships ("culture must thus always be seen as a vehicle or a medium whereby the relationship between groups is transacted" [1993,34]), but how those relationships were figured changed markedly when cultural studies crossed the Atlantic. What began in Birmingham as a political project and commitment to radical social change had been transformed in the United States into postmodern pluralism and discussions of group identity ("a postmodern effacement of the boundaries of high and low, the pluralism of the microgroups and the replacement of ideological politics with image and media culture" $[\mathrm{rg93}, 20])$. Yet, he argued, groups are inherently antagonistic, since it is only through differentiating themselves from the other that groups can identify themselves. For Jameson this differentiation inevitably takes the form of envy or loathing.

At the same time, Jameson called cultural studies "a desire" and "a symptom." That desire is to be "organic intellectuals," which is to say, Gramsci's notion of intellectuals who are also activists and members of their community/class. For Gramsci, it was intellectuals' task to teach and inform their own class. Jameson contended, however, that this desire is impossible. Intellectuals cannot be full social participants because they risk losing the insights they have acquired. Because they know what others of the group do 
not, this knowledge constitutes a kind of power that keeps them separate and perpetual observers ( $1993,39-40$ ). Jameson saw in intellectuals' attraction to cultural studies a desire to participate that he labeled "populism" and that he felt was a denial of the intellectual's true status. Jameson extended his argument to current references to the "body," suggesting that the word be struck from use for a decade. His complaint was that intellectuals use the body as an appeal to immediacy. The concern with the body is a sign of loss of immediacy and a longing for it, much as intellectuals long to participate wholly in society. However, he said, it is not the body but images and stereotypes of the body that are so prolific and that interfere "with a full phenomenological approach to the body itself." The body "is therefore a theme that is always to be historically problematized and never taken as an interpretive code in its own right" (44). Jameson's views on intellectuals' status and the body are worth noting not only for what they say about cultural studies but for how dance studies may respond to them. This issue will be taken up shortly.

\section{Cultural Studies in Crisis}

More critiques of cultural studies have followed since the early I990s, and today the field is often referred to as being in crisis (Ferguson and Golding 1996; Readings 1996; McChesney 2002; Baetens 2005; Grossberg 2006). Lawrence Grossberg recently summed up the issues surrounding cultural studies and suggested ways to proceed in the future (2006). He acknowledged that cultural studies'original leftist political orientation was part of a specific historical conjuncture that has changed (thereby disposing of any remnants of the socialist project). At the same time, he said, cultural studies has hardened into a center in which certain kinds of questions, assumptions, and theories are dominant. Due in large part to its being folded back into the disciplines, cultural studies has become what is essentially an interpretive field that looks at the cultural construction of reality through texts. Culture thus becomes an object of study. Grossberg nevertheless conceives cultural studies in terms of textual interpretation, for he goes on to say that instead of reading texts in relation to a totality of social life that is material, experiential, and meaningful, cultural studies has come to focus on what audiences do with texts. In addition, cultural studies has most often been framed by what Grossberg calls "an assumed otherness of difference" $(2006,9)$ that is, by an emphasis on subjective differences that fragment rather than unite. All of these tendencies have made the field unable to adequately analyze what is happening at the present time.

In his article Grossberg struggles with the issue of interdisciplinarity, of how cultural studies, having been so much absorbed by literature in the United States, is any longer an interdiscipline. He argues that textual culture may no longer be where change is being organized and experienced nor where resistance occurs: "This need not be taken to mean that culture does not matter but that the ways in which it matters-and hence, its effects-have changed in ways that we have not yet begun to contextualize or theorize" $(2006,17)$. In his call for cultural studies to rethink itself, he contends that the field should move toward analyses of the space between culture and economics. This would demand a thorough mastering of the field of economics, which would redeem cultural studies' 
interdisciplinarity and at the same time regain the field's dedication to the contextual analysis of pressing contemporary problems. In addressing economics, the field would move into the center of current power struggles, which for Grossberg revolve around how modernity is to be shaped in the future.

Grossberg's solution to cultural studies' troubles has certain difficulties of its own. These are due primarily to an ambivalent attitude toward cultural studies' relationship to textuality. While assuming that textual analysis is the basis of cultural studies, Grossberg inveighs against the sacred status that theory has assumed in the field and shows uneasiness with textuality itself. At one point he asks, "Is it always necessary that people relate to culture through texts and that its effectivity is always through processes of signification and subjectivity?" $(2006,23)$. Grossberg cannot adequately answer his own question because for him experience and meaning are limited to discourse.

Other recent critiques of cultural studies both reflect and amplify Grossberg's concerns. For example, in their edited collection American Cultural Studies, Catherine Warren and Mary Douglas Vavrus call for political engagement to return to the center of cultural studies' mission $(2002,2)$. This would re-attach the field to concrete issues and in the process help it regain an element of interdisciplinarity. Joanna Zylinska, in The Etbics of Cultural Studies (2005), argues for a sense of responsibility in the field that would recapture early cultural studies' dedication to social change and bring what has been a latent aspect of cultural studies into the open (28-29). Zylinska also notes a growing criticism of the emphasis on identity and difference in intellectual work, mentioning Slavoj Zizek and Alain Badiou as two thinkers who advocate a return to "oneness" as a necessary condition for political action (2005, xi, xiii). Although Zylinska supports attention to difference, it is with the aim of actively finding ways of coming to terms with it. She argues that the cultural studies project demands such action in that it "involves an ethical injunction, an obligation and a call to responsibility" (2005, xi). In both Zylinska's study and Warren and Vavrus's collection, one senses an impatience with cultural studies' preoccupations with discursive analysis and a wish to actively work for social and political change.

\section{Dance Studies/Cultural Studies}

What does this accumulated history and critique of cultural studies mean for dance studies? To begin with, it reinforces cultural studies' own notion of historical contingency; the field has not remained static since the height of Birmingham's Centre for Contemporary Cultural Studies. What I want to argue here is that while dance has benefited from the legacy of early cultural studies, it can avoid some of the pitfalls that have troubled that field, particularly as it has developed in the United States. Certainly cultural studies has helped give dance new freedom: it opened the door to critical theory, gave the field a greater awareness of historical contingency and dance's connections to broader social and political issues, and gave dance scholars permission both to cross disciplinary boundaries and to work in the spaces between them. This is the legacy of early cultural studies, and it radically changed dance research. A mature generation of dance scholars that has absorbed the ideas and methods of cultural studies is now working in the field, among 
them Susan Manning, Susan Foster, Mark Franko, Randy Martin, Ann Daly, and Barbara Browning. And the next, far larger generation is already at work, scholars including Anthea Kraut,Jens Giersdorf, Rebekah Kowal, David Gere, Thomas DeFrantz, and many more. Although there are a number of researchers within the dance field who continue to employ old models, reflecting the spectrum of work that exists in all fields, the most influential research incorporates elements that cultural studies pioneered.

Dance, though, is not altogether like cultural studies in that it does not only adopt methods and theories from other sources-it has its own. To this degree, dance studies resembles humanities disciplines that have incorporated aspects of cultural studies rather than cultural studies itself. For most dance scholars, dance, however it may be defined, has abiding interest as a source of insight into changing social conditions. This contrasts with cultural studies where, as Stuart Hall once remarked, popular culture was of interest to him only because it was a site where socialism might be constituted, otherwise he cared nothing about it (1981, 239).

Dance's theories and methods are used to analyze the human body in motion, and they are valuable no matter how dance is viewed in terms of global performance, where categories are often different from Western ones, or how much we broaden our definition to include a wide variety of human movement. Dance's theories and methods are no more stable than any others; they are open to critique and they change, but they nonetheless constitute a fluid body of ideas, analytical techniques, and vocabularies that focus on questions that scholars in other fields do not ask-questions such as how bodies consume space, how they relate to each other, how their actions both represent and constitute meaning, and what the relationship is of observing bodies to acting bodies, including the scholar's body. Dance's methods and theories, coupled with others beyond its confines, are what may help the field avoid some of the problems of cultural studies, problems that, according to Grossberg, have narrowed cultural studies' focus and brought it closer to disciplinary status.

The preceding pages have shown how cultural studies' emphasis on textuality and theory at the expense of what Janet Wolff called "life experience" and the "real" came to be strongly criticized, especially once the field had been established in the United States. Although in the last several decades dance studies has had its share of uncritical enthusiasm for critical and cultural theory, there has also been a tendency toward a more balanced approach. This is undoubtedly due to dance scholarship's long connection to the social sciences, specifically anthropology, as well as to history. But it is also due to its analytical focus. Where elements of discourse theory, for example, have not fit, they have been called into question. Sociologists Bryan Turner and Steve Wainwright used empirical research on dancers' aging and injury to critique radical constructivist views of the body (Turner and Wainwright 2003; Wainwright and Turner 2006). Helen Thomas is now greatly expanding research on dance injury in part to demonstrate the limits of certain kinds of discursive theory, as well as to show how corporeal restrictions impact dance as a capitalist industry. ${ }^{15}$ One might also point to Susan Foster, whose early work drew on Barthes and Foucault and who has since developed a corporeal theory that, although continuing to acknowledge important debts to discourse theory, has put her 
closer to what she has called the "meat and bones" of human bodies. Foster has attempted to draw theory and practice closer together with the help of Gramsci's concept (through Marx) of praxis as theoretically informed practice (Foster 2005, 2I) ${ }^{16}$

Dance scholars' focus on the living body has brought them, in a sense, down to earth. This does not mean that theory is dead or that dance has not benefited from the golden age of theory through which we have recently passed. We cannot anymore ignore the ideas of the last fifty years than twentieth-century artists could ignore cubism. But due both to the field's history and focus on the body, dance scholars may be less inclined to lose sight of concrete experience than are those in fields that deal solely with signs and images. The intertwined concerns of representation and the moving body as a concrete, though culturally permeated and perceived, entity bas had the effect of stressing an interdisciplinarity in dance studies that has been eroded in U.S. cultural studies.

As for Jameson's contention that all discussion of the body should be avoided on the basis that "nothing is more disembodied than such references to the body" (1993, 44), I can only say that while this argument may be justified in fields dealing with pure representation, it is less convincing in those concerned with living bodies. It is, perhaps, our historical moment that makes representation alone seem inadequate. How are we to account for human beings tortured, blown apart, or sent leaping from hundredstory buildings as merely signs? Despite the fact that most of our experience of these occurrences comes through images, the consequences are too horrific, too "real" to be accounted for solely in representational terms. As hoary as it sounds, our connection to these images may depend on John Martin's idea of metakinesis and humans' neurological response to pain and injury, even when the human body only encounters such trauma through representations. At least, this is the kind of question dance scholars can investigate. Jameson himself acknowledged the "visceral effects" of those essays in Cultural Studies that dealt directly with bodily response and argued that it was only in such cases that the body should be discussed (Jameson 1993, 44). But Jameson's warning against using the body as an appeal to immediacy must also be taken seriously. ${ }^{17}$ Our responses are for the most part culturally constructed, as are the ways in which we view the body. It is for dance scholars to look into how, where, and under what conditions the moving body is perceived in particular ways. Dance studies, armed with theory and methods from many sources, including its own, can make valuable contributions to an understanding of the place of human beings within historical conjunctures by working in the area of tension between representations of the body and, in the broadest sense, the live body in performance.

As cultural studies has moved toward disciplinarity, we have seen that one reaction from scholars has been a desire to reignite the field's early dedication to sociopolitical action, which they view as having been diminished. This return to politics may be seen as a way to regain some of cultural studies' lost interdisciplinarity since political engagement was a key factor in pushing cultural studies beyond disciplinary confines. The lesson here for dance studies is that interdisciplinarity does not just mean taking on theories from other disciplines but also moving a field outward into the world and its concerns. Dance studies has already become more engaged thanks to a broader vision of dance's 
role in society, in large part absorbed from cultural studies. Dance studies does not owe allegiance to any specific ideology, as did early cultural studies, so it can be flexible in addressing current issues. Political positions, though, have been and will be taken in dance scholarship. ${ }^{18}$ Although these positions may be more varied than those of early cultural studies, they should be fairly overt, thanks to current methods that demand clarifying the writer's theoretical framework.

Political action in dance studies can come in different ways and degrees. Early cultural studies taught that intellectual work can be a form of political action, but it also taught that to be political intellectual work must be engaged with real issues. Dance scholars have made contributions in several areas, particularly those of race, gender, and the effects of colonialism. But there is a great deal more work to do. In today's political climate, it is becoming clear that if scholars are to have any impact they must reach out beyond local interests to find common ground with others. While defining individual and group identity may have been crucial in the past, now it is vital to find shared interests among diverse groups. As part of dance's interdisciplinary project, outreach must extend not only to other areas of the intellectual community but beyond the academy. If common interests reach critical mass, they can lead to social change. But change is unlikely without that greater vision. Dance scholars must be able to demonstrate to a larger community how bodies in motion relate to issues that have meaning beyond what is often considered a small, elitist world of little consequence. This can be done through research projects that reach across and beyond disciplinary boundaries, but it can also be helped in modest ways, including casual conversations with people outside the field, by simply explaining how one's research is connected to issues that matter.

In some instances dance scholarship can also lead to more direct social and political action. One thinks of David Gere, whose scholarly research has developed beside his AIDS activism in both writing and through engagement in projects to stop AIDS. Beginning in the I980s while a dance critic in the San Francisco Bay Area, Gere worked on the AIDS Quilt project and helped in other ways to promote AIDS awareness. After taking a teaching position at the University of California at Los Angeles (UCLA) in the early 1990s, he wrote How to Make Dances in an Epidemic: Tracking Choreograpby in the Age of AIDS (2004). The book defined dance to include not only theatrical performances but also funerals, demonstrations, and other structured uses of the body in grief and protest. Gere was a participant in many of these events. More recently, he has enlarged his scope to work with artists in varied media in India, Africa, and Latin America, bringing them together for events and exhibitions through his organization, Make Art/Stop AIDS. His intellectual and activist work, he says, is of a piece. He constantly returns to cultural theory, particularly the work of Douglas Crimp, to inform his varied activities, and he continues to write and teach on how art can help stop AJDS. ${ }^{19}$

In another example of activism, Susan Foster has written of her participation in the 1999 World Trade Organization protests as part of a project on how bodies contribute directly to political resistance, becoming both representations of protest and actual physical impediments (2003). She analyzed how bodily actions created embodied protest in the civil rights lunch counter sit-ins in the r 960 s and Act/Up demonstrations for 
gay rights in the I970s, as well as in the World Trade Organization protests in which she participated.

In yet another instance of activism coupled with intellectual work, Jens Giersdorf wrote of his experience in East German protests in relationship to an analysis of two dances by German choreographers. He began by recalling his corporeal sensations in I 989 while crossing from East to West Berlin as the wall fell and after he had spent many months participating in demonstrations in his native East Germany. He considered his own movements that day as helping to create a cultural construct of embodied movement. Drawing on Mark Franko's concept of replay, Giersdorf argued that such constructs do not immediately vanish but continue to live through replaying in a variety of situations. In his analysis (2003), replay occurred in subsequent works by East and West Berlin choreographers that dealt with East German identity. Thus, vernacular activities inform and circulate through art. These and numerous other works by dance scholars confound Jameson's view that the intellectual cannot be both a participant and analyst. The human body is key to dance scholars' ability to both analyze and live experience. But whether dance scholars conceive of political action in terms of intellectual work alone or add to it more overt political activism, they have much to contribute to the current intensely political moment.

In his article on the future of cultural studies, Lawrence Grossberg argued that culture is no longer the central site of power struggles. Instead, he specified culture as "textual," and he noted that the old questions and old tools may no longer be useful responses to culture at this historical conjuncture (Grossberg 2006, 22). If culture is viewed in terms of bodies in motion in addition to text or discourse, culture remains at the center of current social and political debates. What, for example, could be more central than acts of terrorism and their consequences? As we know from experience, economics alone cannot explain such acts. Culture, as a whole way of life, still makes a difference, both as physical act and as sign. Here, even that much maligned form, high art, has something to contribute. In an interview with the New York Times, William Forsythe called his 2006 work Three Atmospheric Studies, which dealt with Middle Eastern terrorism, an "act of citizenship" (Solway 2007). Other choreographers whose work has dealt with social and political critique, ranging from Paul Taylor to Bill T. Jones, might well take a similar view. But whether considering culture in its broadest sense or more narrowly as art, it remains vital to any understanding of what is going on in the world, and dance scholars have a role to play.

\section{Dance in the Academy}

Much of the debate surrounding disciplinary/interdisciplinary issues in the arts and humanities falls into the narrow terrain of academic categorization. How dance studies is and will be organized within the academy in the future has much to do with institutional politics and the power of disciplines. As has been shown, the tendency in U.S. cultural studies has been for disciplines to absorb elements or in some cases all of cultural studies. How dance will eventually be placed within the academy is not yet a settled mat- 
ter, although for the time being the chances do not seem to favor an interdisciplinary structure (see Soussloff and Franko 2002). Artists, though, have long paid little attention to established boundaries, combining movement, speech, electronic media, live sounds, and visual arts of all sorts. And, of course, arts outside the West are often categorized in very different ways; in some cases what the West calls "art" is not separated from other aspects of life, making Western definitions even harder to maintain. Such antidisciplinarity should work against a narrow approach to dance studies. Academic institutions being what they are, however, we are unlikely to have answers anytime soon concerning where dance will eventually be placed in the disciplinary/interdisciplinary framework. This does not mean dance scholars must sit and wait. The unsettled aspect of dance's position may well be positive. ${ }^{20} \mathrm{We}$ can use the freedom cultural studies has given us for all it is worth, joining with colleagues from a variety of fields to ask new questions, broadening conceptions of what constitutes "dance," questioning the canon, debating methods of dance analysis (sorely in need of examination), and engaging in various levels of political action. We can also reach out beyond the confines of the academy to connect with others who share larger concerns and thereby fulfill one of cultural studies' key aims: to make a difference in the world.

\section{Notes}

I. It should be noted that cultural studies has not been the only influence on the idea of interdisciplinarity in dance studies, particularly in the United States. Also crucial has been the role of vanguard art of the I96os where, through happenings, performance art, and avant-garde theater and dance, boundaries between artistic categories were regularly attacked. For this line of influence see Banes I993a, I993b; Goldberg 1990; Soussloff and Franko 2002.

2. My analysis begins and ends in the United States. The situation may well be different elsewhere, but it is hoped the landscape described will be recognizable enough to be helpful beyond U.S. borders.

3. The conference, chaired by Susan Foster, brought together scholars from a number of disciplines to discuss the body in movement. It was the first time such an event had occurred in the U.S. dance field, and it marked a watershed. The varied viewpoints, plus the participants' incorporation of critical theory and their easy use of theoretical vocabularies and concepts, posed a challenge to established models of dance scholarship. Foster later called the conference "an interdisciplinary moment" (1995, vii), although in this case, "interdisciplinarity" referred primarily to the fact that scholars from several disciplines met to discuss a subject of common interest.

4. Cultural studies also did not conform to a model of interdisciplinarity often seen in academic programs. Hall, speaking of cultural studies as it was developing in England in the 1960s, noted that, "What we discovered was that serious interdisciplinary work does not mean that one puts up the interdisciplinary flag and then has a kind of coalition of colleagues from different departments, each of whom brings his or her own specialization to a kind of academic smorgasbord from which students can sample each of these riches in turn" (Hall r990, 16). Rather, Hall wrote, cultural studies was bent on raiding various disciplines, taking elements from one or another that would enable new concepts to be developed and that would destabilize old categories and ways of thinking.

5. During the I920s and I930s, F. R. Leavis, a literary critic and Cambridge don, with his wife Q.D. Leavis, I. A. Richards, and their students, changed literary analysis and the place of English in the university. Their methods stressed "close readings," that is, rigorous critical analysis and 
careful attention to "the word on the page." Their goal was not simply aesthetic but moral, to save civilization from what they felt were the brutalizing effects of industrialized society. They published much of their work in their influential journal, Scrutiny. See Eagleton 1983 for an introduction to Leavis and the Scrutiny group.

6. Hoggart and Williams have been criticized as nostalgic for a disappearing past and for idealization of the working class. For critical analysis of the work of Hoggart, Williams, and Thompson in relation to cultural studies see Hall I98ob and Turner 2002, chapter 2. For Williams's rebuttal, see Williams 1989 .

7. Some forty years later, Lawrence Grossberg would define conjuncture as "a description of a social formation as fractured and conflictual, along multiple axes, planes and scales, constantly in search of temporary balances or structural stabilities through a variety of practices and processes of struggle and negotiation" (Grossberg 2006, 4), and through Stuart Hall in less verbose terms as "a moment defined by an accumulation/condensation of contradictions, a fusion of different currents or circumstances" (Grossberg 2006, 5)

8. Hall, himself, was an immigrant from Jamaica, born into what he has called a lower-middleclass family.

9. Hoggart was forty-four and a respected Auden scholar when he went to Birmingham. Once ensconced in the English department, he announced his intention of starting a center for cultural studies. This was met with hostility both by the English and sociology departments. The attitude changed little over the years, and CCCS remained marginalized and weak, despite its achievements. The Centre for Contemporary Cultural Studies, renamed the Department of Cultural Studies and Sociology, was closed at the University of Birmingham in 2002 (Webster 2004, 253; see also Hoggart 1957/2006; Hall I980a, 1990).

Io. Thompson joined the Communist Party in the r 930 , leaving it, like many others, after the Soviet invasion of Hungary in 1956 . He remained active throughout his career in leftist politics.

II. Hoggart, Williams, and Hall earned degrees in literature, Hoggart at Leeds, Williams at Cambridge, and Hall at Oxford. Hall mentions that "nearly all of us who entered the cultural studies project were actually formed in the Leavisite ethos" (1990, $\mathrm{r}_{4}$ ).

12. With few exceptions, Cultural Studies reproduces the papers and panel discussions of the I990 conference.

13. Although Hall makes his critique in terms of "textuality," cultural studies had been bothered by a complex of binaries from its beginnings. Early on there was the problem of working between aesthetics and anthropology, which was apparent in Hoggart and Williams's work (see Hebdige 1979/1996, 5-8), and then, more importantly, between what Hall called a "culturalist" strand (already clear in cultural studies' foundational texts) and structuralism (see Hall r98ob) by which he meant between human experience and objectivist structures, consciousness and historical conditions (see also Pfister 1996; Turner 2002).

14. In an article making a case for interdisciplinary departments within the university, Catherine Soussloff and Mark Franko write of how literature departments have absorbed cultural studies and how they treat every object as a text and as representation (Soussloff and Franko 2002).

15. Personal communication January 27, 2008. See also the project Web site, http://www danceinjuries.org.

16. Cultural studies scholars at CCCS also enlisted Gramsci to provide a link between culturalism and structuralism. See Hall rg8ob.

17. For a warning of the dangers of using the dancing body as a sign of nature, immediacy, or authenticity, see Wolff 1995 .

18. Here I am not addressing the question of when and how a dance may be defined as political (see Franko 2006) but rather the position of dance scholars and how they analyze and in some cases experience dances and dance. I am also defining politics broadly to include social issues that, as cultural studies has demonstrated, are political. 
I9. Personal conversation, August 30, 2007.

20. This is not to deny the obstacles institutions erect to maintain the status quo, obstacles that can profoundly influence individual careers. George Lipsitz addresses this issue in American Studies in a Moment of Danger (200I), finding an answer in taking power through communal action.

\section{Works Cited}

Banes, Sally. 1993a. Democracy's Body: Judson Dance Theater, 1962-1964. Durham, NC: Duke University Press.

—_ 1993b. Greenwich Village 1963: Avant-Garde Performance and the Effervescent Body. Durham, NC: Duke University Press.

Batens, Jan. 2005. "Cultural Studies after the Cultural Studies Paradigm." Cultural Studies ig (I): I-I3.

Bryson, Norman. 1997. "Cultural Studies and Dance History." In Meaning in Motion: New Cultural Studies of Dance, edited by Jane C. Desmond. Durham, NC: Duke University Press.

Centre for Contemporary Cultural Studies (CCCS). 1982. The Empire Strikes Back: Race and Racism in 70 Britain. London: Hutchinson in Association with the Centre for Contemporary Cultural Studies, University of Birmingham.

Desmond, Jane C. 1993. "Embodying Difference: Issues in Dance and Cultural Studies.” Cultural Critique 26 (Winter): 33-63.

-, ed. 1997. Meaning in Motion: New Cultural Studies of Dance. Durham, NC: Duke University Press.

Eagleton, Terry. 1983. Literary Theory: An Introduction. Minneapolis: University of Minnesota Press.

Ferguson, Marjorie, and Peter Golding, eds. 1997. Cultural Studies in Question. London: Sage.

Foster, Susan Leigh, ed. 1995. Choreograpbing History. Bloomington: University of Illinois Press.

- 2003. "Choreographies of Protest." Theatre Journal 55 (3): 395-412.

- 2005 "Dance Theory?" In Teaching Dance Studies, edited by Judith Chazin-Bennahum. New York: Routledge.

Franko, Mark. 2006. "Dance and the Political: States of Exception." Dance Research Journal 38 (I\&2): $3-18$.

Gere, David. 2004. How to Make Dances in an Epidemic: Tracking Choreography in the Age of AIDS. Madison: University of Wisconsin Press.

Giersdorf, Jens Richard. 2003. "Border Crossings and Intra-National Trespasses: East German Bodies in Sasha Waltz's and Jo Fabian's Choreographies." Theatre Journal 55 (3): 413-32.

Goldberg, RoseLee. 1990. Performance Art from Futurism to the Present. Rev. ed. London: Thames and Hudson.

Grossberg, Lawrence. 2006. "Does Cultural Studies Have Futures? Should It? (Or What's the Matter with New York?): Cultural Studies, Contexts and Conjunctures." Cultural Studies 20 (I): I-32.

Grossberg, Lawrence, Cary Nelson, and Paula Treichler, eds. 1992. Cultural Studies. London: Routledge.

Hall, Stuart. I980a. "Cultural Studies and the Centre: Some Problematics and Problems." In Culture, Media, Language: Working Papers in Cultural Studies, r972-79, edited by Stuart Hall. London: Hutchinson.

- 1980b. "Cultural Studies: Two Paradigms." Media Culture and Society 2: 57-72.

- 198r. "Notes on Deconstructing 'the Popular." In People's History and Socialist Theory, edited by Raphael Samuel. London: Routledge.

- 1990. "The Emergence of Cultural Studies and the Crisis of the Humanities." October 53 (Summer): $1 \mathrm{I}-23$. 
- I992. "Cultural Studies and Its Theoretical Legacies." In Cultural Studies, edited by Lawrence Grossberg, Cary Nelson, and Paula Treichler. London: Routledge.

Hall, Stuart, Chas Critcher, Tony Jefferson, John Clarke, and Brian Roberts. 1978. Policing the Crisis: Mugging, the State, and Law and Order. London: Macmillan.

Hall, Stuart, and Tony Jefferson, eds. 1976. Resistance Through Rituals: Youth Subcultures in Post War Britain. London: Hutchinson.

Hebdige, Dick. 1979/1996. Subculture: The Meaning of Style. London: Routledge.

Hoggart, Richard. 1957/2006. The Uses of Literacy: Aspects of Working-Class Life with Special References to Publications and Entertainments. With a new postscript by John Corner. London: Transaction.

hooks, bell. 1992. "Representing Whiteness in the Black Imagination."In Cultural Studies, edited by Lawrence Grossberg, Cary Nelson, and Paula Treichler. London: Routledge.

Jameson, Fredric. 1993. "On 'Cultural Studies.'" Social Text 34: 17-52.

Koritz, Amy. 1996. "Re/Moving Boundaries: From Dance History to Cultural Studies." In Moving Words, Re-writing Dance, edited by Gay Morris. London: Routledge.

Lipsitz, George. 2001. American Studies in a Moment of Danger. Minneapolis: University of Minnesota Press.

Manning, Susan. 2006. “Letter from the President." Society of Dance History Scholars Newsletter $26(\mathrm{I}): \mathrm{I}-2$.

McChesney, Robert W. 2002. "Whatever Happened to Cultural Studies?" In American Cultural Studies, edited by Catherine A. Warren and Mary Douglas Vavrus. Urbana: University of Illinois Press.

Pfister, Joel. 1996. “The Americanization of Cultural Studies." In What Is Cultural Studies? edited by John Storey. London: Arnold.

Readings, Bill. 1996. The University in Ruins. Cambridge, MA: Harvard University Press.

Solway, Diane. 2007. "Is It Dance? Maybe. Political? Sure." New York Times, February I8: AR 33 .

Soussloff, Catherine, and Mark Franko. 2002. "Visual and Performance Studies: A New History of Interdisciplinarity." Social Text 20 (4): 29-46.

Thompson, E. P. 1963. The Making of the English Working Class. London: V. Gollancz.

Turner, Bryan S., and Steven P. Wainwright. 2003. "Corps de Ballet: The Case of the Injured Ballet Dancer." Sociology of Health and Illness 25 (4): 269-88.

Turner, Graeme. 2002. British Cultural Studies: An Introduction. 3rd ed. London: Routledge.

Wainwright, Steven P., and Bryan S. Turner. 2006. "Just Crumbling to Bits'? An Exploration of the Body, Ageing, Injury and Career in Classical Ballet Dancers." Sociology 40 (2): 237-55.

Warren, Catherine A., and Mary Douglas Vavrus, eds. 2002. American Cultural Studies. Urbana: University of Illinois Press.

Webster, Frank. 2004. "Cultural Studies and Sociology at, and after, the Closure of the Birmingham School." Cultural Studies I8 (6): 947-62.

West, Cornel. I992. "The Postmodern Crisis of the Black Intellectuals." In Cultural Studies, edited by Lawrence Grossberg, Cary Nelson, and Paula Treichler. London: Routledge.

Williams, Raymond. 1958/1983. Culture and Society, $1780-1950$. With a new introduction by the author. New York: Columbia University Press.

- 196r. The Long Revolution. London: Chatto and Windus.

- 1989. The Politics of Modernism: Against the New Conformists. London: Verso.

Willis, Paul. 1977. Learning to Labor: How Working Class Kids Get Working Class Jobs. New York: Columbia University Press.

Wolff,Janet. I992. "Excess and Inhibition: Interdisciplinarity in the Study of Art."In Cultural Studies, edited by Lawrence Grossberg, Cary Nelson, and Paula Treichler. London: Routledge.

- 1995. Resident Alien: Feminist Cultural Criticism. Cambridge: Polity Press.

Zylinska, Joanna. 2005. The Ethics of Cultural Studies. London: Continuum. 